\title{
The ministry of hope at grassroots level in a post- apartheid South Africa
}

\begin{abstract}
Author:
Amanda L. du Plessis ${ }^{1}$

Affiliation:

${ }^{1}$ Practical Theology, Faculty of Theology, North-West University, South Africa
\end{abstract}

\section{Correspondence to:}

Amanda L. du Plessis

\section{Email:}

amanda.duplessis@nwu.

ac.za

\section{Postal address:}

Villa Louanne 79, Weyer

Street, Potchefstroom 2520

South Africa

\section{Dates:}

Received: 04 Apr. 2013

Accepted: 08 Aug. 2013

Published: 26 Sept. 2013

How to cite this article:

Du Plessis, A.L., 2013,

'The ministry of hope at grassroots level in a postapartheid South Africa', In die Skriflig/In Luce Verbi 47(1), Art. \#715, 6 pages. http:// dx.doi.org/10.4102/ids. v47i1.715

Note:

Paper was delivered at the 5th global conference on 'Hope: Probing the boundaries', held by Interdisciplinary.net, Lisbon, Portugal, 10-12 March 2013.

\section{Copyright:}

C 2013. The Authors.

Licensee: AOSIS

OpenJournals. This work

is licensed under the

Creative Commons

Attribution License.

Read online:

Scan this QR
code with your
smart phone or
mobile device
to read online.

In this article the the ministry of hope to women without hope are investigated in the South African context of hope and reconciliation. Since apartheid ended 19 years ago, a democratic policy has been followed. The Truth and Reconciliation Commission was assigned the task to lead the population of South Africa to hope and reconciliation. The question may truly be asked whether the current picture could be that of a healed country. On the one hand, a large part of the population demonstrates a negative attitude regarding future expectations of South Africa; on the other hand, there are people at grassroots level who strive daily to bring about reconciliation in society by trying to make life easier for others. Utilising the available resources, which are minimal, the women called Mamas Africa are examples of people who serve the hopeless with hope every day. The central theoretical argument is that the Mamas Africa phenomenon has the potential of bringing hope, should it branch out widely. The concept of Mamas Africa refers to women from all races who promote mutual commitment based on their faith, and also make a difference in the South African society. In this article, an empirical investigation was made into the motivation behind the Mamas Africa phenomenon in the first place. Secondly, a normative investigation was conducted into the theology of hope from the perspective of reformed theology; and finally, pragmatic guidelines have been provided for the ministry of hope to the hopeless in the South African society.

Die bediening van hoop op grondvlak in post-apartheid Suid-Afrika. In hierdie artikel word die bediening van hoop en versoening aan oënskynlik hooplose vroue ondersoek in die SuidAfrikaanse konteks van hoop en versoening. Dit is reeds 19 jaar sedert apartheid afgeskaf is en 'n demokratiese beleid in Suid-Afrika gevolg word. Die Waarheids- en Versoeningskommissie (WVK) is getaak om die bevolking van Suid-Afrika na hoop en versoening te lei. Dit wil egter voorkom asof die bevolking van Suid-Afrika tans verder van rekonsiliasie is as direk na 1994. Die vraag kan tereg gevra word of dit ' $n$ beeld is van ' $n$ land wat genesing beleef. Ondanks die staking van die WVK se werksaamhede en die oorwegend negatiewe ingesteldheid van 'n groot deel van die bevolking rakende die toekomsverwagtinge in Suid-Afrika, is daar diegene op grondvlak wat elke dag daarna streef om versoening in die samelewing te bewerkstellig deur die lewe van ander te probeer vergemaklik. Die vroue genaamd 'Mamas Afrika' is voorbeelde van diegene wat, met die minimum hulpbronne tot hulle beskikking, daagliks die hooploses met hoop bedien. Die konsep Mamas Afrika verwys na vroue van alle rasse wat hulle, as uitvloeisel van hulle geloof en vertroue in God, beywer tot onderlinge versoening. Die vraag wat hier ter sprake is, is die volgende: Wat is die relevansie van die Christelike hoop en versoening as dryfveer vir morele aksie in die Suid-Afrikaanse samelewing se groei na versoening en nasiewording soos toegepas deur die Mamas Afrika?

\section{Introduction}

Since apartheid ended 19 years ago in South Africa, a democratic policy has been followed. During the time of transition, the South African population was broken and fragmented. In an effort to lead the country to reconciliation and unity, the governing party, the African National Congress (ANC), established a commission that tried to bring about reconciliation over a period of three years. The Truth and Reconciliation Commission (TRC) was assigned the task to lead the population of South Africa to hope and reconciliation. International experience shows that dealing with human rights violations from the past is a necessary step in the process of reconciliation and nation-building (Barry 2006:691). According to the chairperson of the TRC, Desmond Tutu, the task of the TRC was only to encourage reconciliation and not to attain it completely (Tutu 1998):

... to remind us all that the TRC is expected to promote, not to achieve, reconciliation. Reconciliation has to be the responsibility of all South Africans, a national project - and we hope that the churches and other faith communities will be in the forefront of this healing process which is possibly going to go on for decades. We have all been deeply wounded and traumatized and it will take long to undo centuries of the alienation and animosity that were deliberate state policy. (p. 6) 
The population of South Africa was reminded that reconciliation was a national project and the hope was cherished that churches and other institutions of faith would become involved in continuing reconciliation. Krog (1998) referred to the work of the TRC as a national ritual and stated:

\begin{abstract}
... the television news ritual; the ritual of choosing a venue for the hearings in a town; the inaugural worship service in the local township on the Sunday before the hearings commence; the acknowledging of a sacred space for victims; initiation into being one of the few who have been chosen; the exorcism of terrible memories; becoming part of the blessed greater community; and finally the subtle 'scapegoat' ritual that suggests they were always responsible (thus creating a nation of martyrs). (p. 5)
\end{abstract}

But Krog (1998) would later remark that to bring about a national ritual, the entire population had to be involved in rectifying the wrongs of the past and present, something the TRC did not succeed in:

And so my instinct is to say that the TRC has failed at this stage to come up with a national ritual of reconciliation. I would even go so far as to say that it is actually impossible for the Commission to establish a national ritual - as the essence of a ritual is the connection, the community, the group and what the Commission is doing is to show why we have never been (nationally) a group, a community. What the Commission does do, however, is to put who we are on the table. I now know what happened, and who did it, and what my role in it was. And so, deep down all of us are negotiating and wrestling with ourselves about these facts and emotions. Thus I would agree that the TRC is at least making it possible for South Africans to work towards a national ritual. Because we are getting a better understanding of who we are, we will be able to do work towards a deeper connectedness. (p. 16)

The testimonies at the TRC gave rise to very diverse reactions from the population of South Africa. Some welcomed the public platform and felt their human dignity was given back to them. Others were amazed and shocked, and confessed that they were entirely ignorant about the events of the past. Some ignored the activities at the TRC in an apathetic manner, but at the same time the reality of the new system left them with increasing insecurities. In retrospect, the pain of the involved seems to have been relieved by the work of the TRC. However, the TRC did not succeed altogether in leading the population to a hopeful future by bringing about in-depth reconciliation. If that had been the case, the reconciliation process would have retained its momentum. Currently, it seems as if the population of South Africa is even further from reconciliation than in the years directly after 1994. Poverty, corruption, racism, crime and emigration of skilled persons are still amongst the biggest challenges confronting South Africa. According to Boraine (2008:215), the South African population has to experience the mutual commitment of ubuntu once again to bring about reconciliation. Ubuntu refers to the essence of the African concept of what it means to be a human being. It is a general term for all the different views embodied in African anthropology. According to Vorster (2011a:1), the concept denotes the African version of human dignity in the South African constitution. For Christians there is a close relationship between hope and reconciliation. Because hope is the secure anchor in the lives of believers (Heb 6:19), reconciliation can flow from it. Reconciliation in society lights the flame of hope again; thus, momentum is gained when people are striving for the common goal of mutual commitment and nation-building.

Despite a part of the population's fears for the future, there are people at grassroots level who strive daily to bring about reconciliation in society by trying to make life easier for others. Utilising the available resources, which are minimal, the women called Mamas Africa are examples of people who serve the hopeless with hope every day. The concept of Mamas Africa refers to women from all races who promote mutual commitment based on their faith, and also make a difference in the South African society. They are motivated by a deep faith in God, who is the source of hope ( $\mathrm{Rm} \mathrm{15:13),}$ and by the conviction that the Christian is given the ministry of reconciliation (2 Cor 5:18-19). Burke (2001) describes the valuable role of these women as follows:

Clearly religious women are a formidable force in the Church of Africa today. Besides their initial work in the establishment of the basic infrastructure and outreach to women and children, they continue to minister to the educational, health, development and pastoral needs of hundreds of thousands on the continent - in many cases, equally to Christians and non-Christians alike. Their presence is far more ubiquitous than clerics. More frequently they are found at the grassroots - truly immersed in the daily realities of their people. (p. 231)

\section{Research question and method}

The question that had to be answered in this article, was the following: What is the relevance of Christian hope and reconciliation as the impetus behind moral action, as applied by the Mamas Africa, in the growth of the South African society to mutual commitment and nation-building?

The research method comprised a combination of studying the subject and applicable literature, and empirical research. This process was aligned with Osmer's four tasks for practical theology, and it will be presented in two sections (Osmer 2008). In the first section of the research, attention was given to the empirical aspects: What is the influence of the Mamas Africa on society?, as well as the interpretative aspects: Why do the Mamas Africa have such a big impact on society?. In the second section, the emphasis fell on the normative aspects: Which norms can be formulated from a reformational departure point in ministering Christian hope and reconciliation in the South African society? Finally, the emphasis is on the pragmatic aspects: In what way can the principles derived from this research be applied by the rest of the South African society, so that its execution can contribute to a national ritual of reconciliation and nation building?

\section{Introducing the Mamas Africa}

The empirical research method followed in this article is a qualitative study intended to construct the cultural context in which the events take place (Neuman 1997:14; Janse van Rensburg 2007a:7; 2007b:8). Three members of the Mamas Africa were chosen to participate in the field study. In observing them and in trying to understand their 
experiences, actions, emotions and the events of which they were part, the focus was on their emotions and sincerity. The participants were selected based on their active involvement in the community as this measure ensured that those selected would be able to give valuable insights into the phenomenon under investigation. The Mamas Africa are women who play leading roles in their community and they are independent from political, church or other institution. These women do not necessarily have a tertiary education, but because of their wisdom and involvement in society, they have a definite influence on society. A brief description of the women follows. All three of them gave permission for their real names to be published.

Mama Susan Luthuli is 79 years old and the founder member and manager of Ikageng Old Age Day Care Centre. She receives no subsidies from the government for the centre and is dependent on sponsors and the good will of others. Her passion was kindled when taking on the care of her own mother and her mother's sister - she became conscious of the need of old age care in the community. She has a deep trust in God as was clear from her fervent testimony to prayers being answered. The helpers at the centre plant vegetable gardens to provide food for the centre. Mama Susan's vision is to restore the honour and human dignity of the aged. She also shared her conviction that she would establish an affordable residential old age home before she dies. When I visited the centre, there were 10 old people on that specific day. They expressed their gratitude to Mama Susan for the safe harbour where they were cared for during the day. They told about their unbearable circumstances before the centre had been founded. Amongst the most shocking stories were those about old people who were eaten by worms, merely because they were too weak to do something about the situation themselves and because there was nobody to help them. In many informal settlements, the old people are easy targets for crime and they are unable to protect themselves. The centre contributes to a better quality of life for the aged.

Mama Meriam Dassie is a 65-year-old widow who, together with three other women, operates a vegetable garden project at the Tlokwe Secondary School in Ikageng. They are also dependent on sponsorships and do all the physical work themselves. From the garden, they provide basic food to approximately 70 orphans daily. Mama Meriam testified that the children did not receive the love of a mother, because their parents had died (mostly because of HIV-related illnesses). As their gogo (grandmother), she could give them love and hope for the future. Mama Meriam said that the principal also approaches her from time to time to talk to the children at openings. She told me that she used this platform to inform them about the negative consequences of drugs and wrong life choices. Although Mama Meriam had no formal education, she has a deep wisdom and understanding of life.

Mama Kaka Masiu is a 36-year-old single mother of three children. She works for a community project funded by endowments from businesspersons. In this project, instructors teach people in the community computer literacy and skills that are needed to find work. Mama Kaka is also actively involved in social work and the teaching of life skills. She testified that she always thought she could only be a domestic worker, i.e. a cleaner of other people's homes, but at that stage she could say that she had become a mind cleaner. During my visit to this project, I also met the 23-year-old Eunice Wesinyana. She is a beautiful young woman who was able to build up networks to develop her interest in photography. To her it meant the fulfilling of a life dream, which would have never been possible if not for the community project. She also acts as a project leader to guide newcomers in their activities. She testified: 'By helping others, I learn new things and help myself. It gives me hope.' Without this community project, many other people would not have had a means of livelihood. The feeling amongst these project leaders is that they do not have the ability to make a big difference globally, but that the difference they make in one person's life, branches out to others. This way momentum is gained in promoting mutual commitment and nation-building.

During my visits to the Mamas Africa, I came deeply under the impression of Paul's words in 2 Corinthians 4:7: 'But we have this treasure in jars of clay to show that this allsurpassing power is from God and not from us' (NIV). These women are just breakable clay jars that contain a treasure they are sharing with others. They are women who have already endured many hardships and challenges in life, but who made the decision to become actively involved in their society in an effort to make life easier for others. I did not notice any bitterness or revolt in any of these women because of their difficult circumstances. They are promoting mutual commitment in society by their small gestures in everyday life. All three of them testified to a relationship with God. Under the guidance of the Holy Spirit, through sincere love, and through the word of truth and the power of God, they minister their fellow human beings with the infallible hope of God. Gestures like these promote reconciliation at grassroots level. To my mind, the uncertainties regarding the future amongst the people of South Africa could also be overcome if the entire population would work together to reach the common goal of mutual commitment and nation-building. Many cultural differences could be bridged by showing a deep respect and recognising each other's human dignity. The Mamas Africa are examples of people who want to encourage involvement of the population and who do not place their hopes blindly and passively on the government. These women have realised that they do not have to be political or church officials to become involved in society. The only thing necessary is a deep faith in God and kindheartedness towards others.

\section{The ministry of hope and reconciliation}

In the second part of this research, the spotlight falls on the theological aspects regarding the ministry of hope and reconciliation. Referring to the model of Osmer (2008), the normative and pragmatic aspects of hope and reconciliation are discussed from a reformational viewpoint. Vos (2007) uses the following metaphor in describing hope: 
Hope is like a lily in muddy water. The lily flowers in this water and like the lily, hope grows in distressful and muddy circumstances. Hope can exist in mud and can live off beauty. But hope also reminds us of our frailty. (p. 11)

This metaphor is a fitting description of the ministry of hope and reconciliation in South African circumstances. Despite the numerous challenges confronting the population and believers every day, they have to make the decision 'to flower'. However, this is only possible if inner change and renewal has taken place through a deep-rooted trust in God. People who are suffering because of a life-changing event in their lives, such as the death of a beloved during the apartheid struggle or because of crime or the facing poverty every day, are the ones in need of hope. The role of hope in striving for reconciliation amongst the people of South Africa should not be underestimated, because Christian hope gives rise to joy and happiness, even in difficult circumstances (Pr 10:28; Rm 5:2-5, 12:12; 1 Th 4:13). Christian hope is also conducive to growth in the faith of the believer and in showing love to others (Col 1:4-5).

\section{The Christian message of hope and reconciliation}

Vorster (2011b:6) refers to Moltmann as the modern exponent of hope. According to Moltmann (1967:15), eschatology has been referred to as the 'doctrine of the last things', or the 'doctrine of the end', for many years. This reference signified the second coming of Jesus Christ in universal glory, the judgment of the world and the establishment of the kingdom, the resurrection of the dead, and the new earth and new heaven. Moltmann (ibid) states, however, that this 'postponement' of hope robs or deprives humanity of hope in the present:

... [T] he relegating of these events to the 'last day' robbed them of their directive, uplifting and critical significance for all the days which are spent here, this side of the end, in history. (p. 16)

The believer's hope is found in Jesus Christ, through whom the kingdom of God is already present in the world, though not completely yet. The Christian is therefore responsible for proclaiming the message of hope and reconciliation (Vorster 2011b:7). Every believer has received the ministry of hope (2 Cor 5:18-19). To guide believers in the ministry, the Holy Spirit and the different gifts of Spirit have been given to them (1 Cor 12). The motivational force behind the ministry of hope and reconciliation in society is Christian love, which is the basis of all the gifts of the Spirit (1 Cor 13; Vorster ibid:7). Moltmann (1975:45) further describes his theology as 'not a theology about hope, but a theology growing out of hope'. The ground for hope, however, is not found in the challenges of the presence, but in the promise of God. Therefore, this leaves the believer to make a paradigm shift. Despite the current circumstances, believers' hope remains anchored in God. Therefore, they can minister the society with hope in present times. Moltmann (1978:19) describes the presence of believers as the representatives of Jesus as follows:

Where Jesus is, there is life. There is abundant life, vigorous life, loved life, and eternal life. There is life-before-death. I find it deeply disturbing and unsettling whenever I think about how we became accustomed to death: to the death of the soul, to death on the street, to death through violence - to death-beforelife. (p.19)

The believer is therefore called upon to bring life through the message of hope and reconciliation. Although it may be easier to be apathetic in certain cases, believers may not retreat into a self-centred life and remain silent about the many challenges experienced by society. Believers' trust and hope in God prompts them to action and become involved in society. Moltmann (1978:19) further states that the believer may not get used to and remain silent about the wrongs of the present. It was Jesus' passion that made him endure the suffering of the cross. Ultimately, it is the covenant relationship between God and the believer that helps the believer to live with the same compassion (Moltmann ibid):

[The believer's] whole life would be shaped by sympathy, by compassion. We would suffer with God's suffering in the world, and rejoice with God's rejoicing over the world. We would do both at the same time and with the highest intensity because we would love, and with the love of God we would go outside ourselves. (p. 23)

One of the most important basic principles of reconciliation is human dignity. This concerns the ubuntu concept, which was mentioned earlier. The 1996 Constitution of South Africa declares human dignity, along with freedom and equality, as a basic democratic value (Vorster 2011a:1). Although concepts such as human dignity and human rights have been connected to Western liberalism and humanistic fundamentalism for many years, violations of human rights lead the church to reflect on these concepts (Vorster ibid:2). Today, the question is not whether the human being would be clad by dignity anymore, but what the contents and the scope of the dignity would be. Nico Vorster (2007:3) concludes that the imago dei, the covenant and social justice, the recreation of Jesus Christ, and the meaning of the concept of the kingdom of God, form the paradigm for a Christian view of human dignity. Vorster (2011a:3) adds another three doctrines of revelation to these as the basis for human dignity, namely (1) the human being as the receiver of the Spirit and the gifts of the Holy Spirit, (2) the human being as the caretaker of the creation, and (3) the human being as the inheritor of the new earth. A Christian perspective of human dignity is that all life must be taken seriously by taking care of the interests of other people and by pleading for the interest of the community above the right of the individual's privacy.

\section{The Christian life of hope and reconciliation in a post-apartheid South Africa}

Christian reconciliation may not be spiritualised, as if it is only found in the domain of the believer's intimate faith relationship with God (Vorster 2011b:13). Reconciliation in Christ also has socio-political implications. In order to answer the research question, the following aspects are presented as the relevance of Christian hope and reconciliation as the impetus behind moral action, as applied by the Mamas Africa, in the growth of the South African society to reconciliation and nation-building: 
- True reconciliation implies a restored relationship with God through Jesus Christ's death of atonement on the cross (Vorster 2011a:81). However, reconciliation also has a horizontal dimension, as believers find themselves in a new relationship with other people. From the example of Jesus' mediatorship, believers must also become active mediators in broken relationships. The Mamas Africa are examples of this mediatorship.

- Hope is a gift of the Holy Spirit and it is the banner of life to believers. Reconciliation with God therefore presents the believer with the ministry of reconciliation, which must be put into practice in society. From the viewpoint of a new relationship with God, believers have the calling to address disunity and to help heal broken relationships (Schwóbel 2003:19). All three Mamas Africa confessed their faith and hope in God as the impetus behind their decision to become involved in the community.

- Reconciliation is concerned with the restoration of relationships. God is the primary author of reconciliation. Therefore, Christian reconciliation may not be attenuated to mere human action in a socio-political milieu (Vorster 2011a:23). The Mamas Africa directed their ministries of hope and reconciliation at all aspects of being a human being. Though they often start off by making a difference in the physical and social aspects in the lives of those to whom they reach out, they always followed it up by psychological and spiritual care.

- Reconciliation with all people is a command of God to be carried out by all believers that receive the calling to promote, in society, the principles flowing forth from the acts of atonement by God, such as peace, justice, integrity, honesty, righteousness, love, care and mercy (Vorster 2011a:24). The TRC transmitted something of these principles in their depiction of confession of guilt, remorse, punishment and restitution as part of the process of healing in South Africa. In order for the national ritual of the TRC to live on, the entire population has to become involved nationally in the daily continuation of this ritual. Through their activities, the Mamas Africa are prepared the rectify mistakes and to make sacrifices for the sake of mutual commitment and a better socio-political dispensation.

- A further aspect that became clear from this empirical investigation is that believers' ministry is not restricted to fellow believers. Believers are also instructed to provide a helping hand to unbelievers and to serve them with the ministry of hope and reconciliation.

In Keim's collective work, uMama (2009), 40 South Africans describe the difference that their mothers or grandmothers have made in their own lives as well in the lives of others in society. In this work, Tutu (2009:164) refers to his mother as Leah, meaning 'the comforter of the afflicted'. Williams (2009:171) describes the extreme poverty they grew up in and in what way his grandmother coloured the mieliepap the only food they had - another colour with food colouring every day: 'It showed the marvellous, gentle, loving way she had of trying to preserve childhood and distracting us from how poor we really were.' He (Williams ibid) continues by saying:
I could see in grandma's eyes a glimmer, that is nothing else but the loving face of God. Maybe there was something more than just colouring and sweetener in that pap. Perhaps what was in that pap was hope itself. (p. 172)

The Mamas Africa are characterised by the hope and reconciliation that they bring across colour and race boundaries in a post-apartheid South Africa in order to promote mutual commitment and nation-building.

\section{Conclusion}

The ministry of hope to bring about (further) reconciliation in South Africa alongside socio-political and moral renewal is, to my mind, the national ritual that Krog wished she saw in the activities of the TRC. The TRC held up a mirror in which the people of South Africa had to look at themselves. Never again would the South African population be able to say: 'We did not knowledge of all that took place at the TRC, decisions were made. Currently, the South African population is left with several challenges that must (still) be addressed and several choices that must (still) be made.

In this article the focus was on women who decided, despite many shortcomings, to become involved in society by bringing hope to those without hope - in this way, they bring about reconciliation that, in turn, brings about a feeling of mutual commitment to promote nation-building.

From a reformational point of departure, it can be seen that hope and reconciliation have vertical and horizontal dimensions. The vertical dimension of hope implies reconciliation between God and the human being, and the horizontal dimension implies reconciliation between human beings. Eventually, these two dimensions form the image of the cross. Through Jesus' reconciliatory death on the cross, his resurrection and the promise of his second coming, the human being has a secure hope. It is because of this hope that believers also receive the ministry of reconciliation with their neighbours.

\section{Acknowledgements Competing interests}

The author declares that she has no financial or personal relationship(s) that may have inappropriately influenced her in writing this article.

\section{References}

Barry, S., 2006, 'Reconciliation: The South African Truth and Reconciliation Commission's contribution to dealing with the past, reconciling and building the nation', In die Skriflig 40(4), 691-714. http://dx.doi.org/10.4102/ids.v40i4.365

Boraine, A., 2008, A life in transition, Struik Uitgewers, Cape Town.

Burke, J.F., 2001, These catholic sisters are all Mamas! Towards the inculturation of the sisterhood in Africa: An ethnographic study, Brill, Leiden.

Janse van Rensburg, J., 2007a, 'Navorsingsmetodologie', paper presented at the North-West University, Potchefstroom, 09 March.

Janse van Rensburg, J., 2007b, 'Navorsingsmetodologie', paper presented the North-West University, Potchefstroom, 30-31 August.

Keim, M., 2009, uMama. Recollections of South African mothers and grandmothers, Umuzi, Cape Town. 
Krog, A., 1998, 'The Truth and Reconciliation Commission - A national ritual?', Missionalia 26(1), 5-16.

Moltmann, J., 1967, Theology of hope, SCM Press, London.

Moltmann, J., 1975, The experiment hope, SCM Press, London. PMid:1130107

Moltmann, J., 1978, The open church. Invitation to a messianic lifestyle, SCM Press, London. PMid:711877

Neuman, W.L., 1997, Social research methods, 3rd edn., Allyn and Bacon, Boston.

Osmer, R., 2008, Practical theology: An introduction, Eerdmans, Grand Rapids.

Schwöbel, C., 2003, 'Reconciliation', in C.E. Gunton (ed.), The theology of reconciliation, pp. 13-38, T\&T Clark, London.

Tutu, D., 1998, 'The Truth and Reconciliation Commission', in C.W. du Toit (ed.) Confession and reconciliation, pp. 4-6, UNISA, Pretoria.
Tutu, D., 2009, 'Thank you God for women, for our mothers', in M. Keim (ed.), uMama. Recollections of South African mothers and grandmothers, pp. 162165, Umuzi, Cape Town.

Vorster, N., 2007, Restoring human dignity in South Africa: Essays in Christian anthropology for a new dispensation, Potchefstroom Theological Publications, Potchefstroom.

Vorster, J.M., 2011a, Menswaardigheid, versoening en vergiffenis, Potchefstroom Teologiese Publikasies, Potchefstroom.

Vorster, J.M., 2011b, 'An ethics of hope for moral renewal in South Africa', Journal of Theology for South Africa 140, 4-19.

Vos, C.J.A., 2007, 'Preaching as a language of hope', in C.J.A. Vos, L.L. Hogan \& J. Cilliers (eds.), Preaching as a language of hope, pp. 5-13, Protea Book House, Pretoria. PMid:17602119

Williams, A., 2009, 'Hope itself', in M. Keim (ed.), uMama. Recollections of South African mothers and grandmothers, pp. 170-173, Umuzi, Cape Town. 